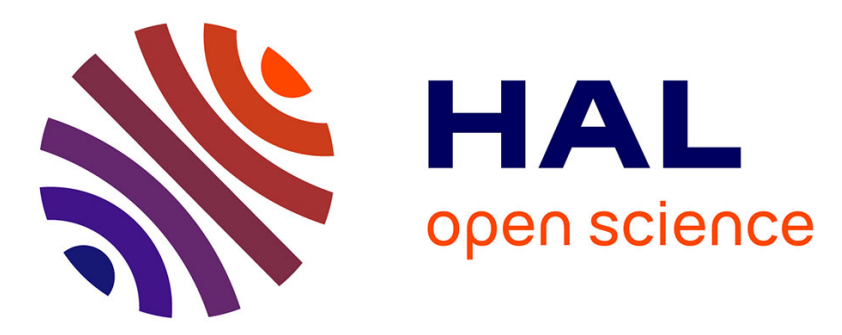

\title{
Low Benthic Macrofauna Diversity in Dynamic, Tropical Tidal Mudflats: Migrating Banks on Guiana's Coast, South America
}

Jérôme Jourde, Christine Dupuy, Hien T Nguyen, David Mizrahi, Nyls de Pracontal, Pierrick Bocher

\section{To cite this version:}

Jérôme Jourde, Christine Dupuy, Hien T Nguyen, David Mizrahi, Nyls de Pracontal, et al.. Low Benthic Macrofauna Diversity in Dynamic, Tropical Tidal Mudflats: Migrating Banks on Guiana's Coast, South America. Estuaries and Coasts, 2017, 10.1007/s12237-016-0205-y . hal-01428844

\section{HAL Id: hal-01428844 https://hal.science/hal-01428844}

Submitted on 6 Jan 2017

HAL is a multi-disciplinary open access archive for the deposit and dissemination of scientific research documents, whether they are published or not. The documents may come from teaching and research institutions in France or abroad, or from public or private research centers.
L'archive ouverte pluridisciplinaire HAL, est destinée au dépôt et à la diffusion de documents scientifiques de niveau recherche, publiés ou non, émanant des établissements d'enseignement et de recherche français ou étrangers, des laboratoires publics ou privés. 
Low benthic macrofauna diversity in dynamic, tropical tidal mudflats: migrating banks on Guiana's coast, South America

Jérôme Jourde ${ }^{1}$, Christine Dupuy $^{1}$, Hien T. Nguyen ${ }^{1}$, David Mizrahi ${ }^{2}$, Nyls de Pracontal ${ }^{3}$, Pierrick Bocher ${ }^{1}$

$\triangle$ Pierrick Bocher pbocher@univ-lr.fr

1 Laboratory Littoral, Environnement et Sociétés (LIENSs) UMR 7266 CNRS-University of La Rochelle, 2 Rue Olympe de Gouges, 17000, La Rochelle, France

2 New Jersey Audubon Society, 600 Route 47 North, Cape May Court House, NJ 08210, USA

3 Groupe d'Etude et de Protection des Oiseaux de Guyane, 16 Avenue Pasteur - 97300 Cayenne, French Guiana

\section{Abstract}

In tropical South America, the mudflats of the Amazonian coast are unique because of their large size and unrivaled migration dynamics. On Guiana's coast, macrofaunal communities are believed to be well-adapted to these dynamic conditions. In this study, the benthic macrofauna was sampled in April 2012 in the Awala-Yalimapo region of western French Guiana and at two sites in Suriname, Warappa Kreek and Bigi Pan, These sites are found 800, 920, and 1,140 km from the Amazon delta, respectively. The richness, diversity, and densities of the macrofaunal communities in these mudflats are here described for the first time. Only 38 OTU were recorded, among which two species were common and widely distributed: the tanaid crustacean Halmyrapseudes spaansi and the polychaete Sigambra grubii; the former represented $84 \%$ of all individuals collected, with densities reaching up to 73,000 individuals. $\mathrm{m}^{-2}$. Most of the OTU consisted of relatively small individuals ( $<10 \mathrm{~mm}$ in length). The very low richness and diversity and the small sizes of the organisms are likely linked to the instability and softness of the substrate on these mudflats. This study suggests that the differences in macrofaunal community composition among sites could be due to the migration stage of banks rather than the distance from the Amazon Delta and associated effects of river discharge. 
Keywords: Amazon influence, tropical mudflats, soft-bottom macrobenthos, communities, dynamic habitat.

\section{Introduction}

The mudflats of the Amazonian coast in South America are unique because of their size and dynamics. The coastline between the Amazon and Orinoco Rivers (ca. 1,500 km long), often referred to as the "Guianan Coast," is considered the muddiest in the world because of the large flow of suspended sediment from the Amazon River (754 Mt $\mathrm{y}^{-1} \pm 9 \%$. Martinez et al. 2009). The fluid mud is transported along the Guianan coast in a series of large migrating mudbanks resulting from complex interaction among waves, tides, wind and coastal currents. The physical dynamics of these mudbanks have been studied extensively in French Guiana (Augustinus 1978; Eisma et al. 1991; Allison et al. 2000; Allison and Lee 2004; Baltzer et al. 2004; Gratiot et al. 2007; Anthony et al. 2010). These migrating mudflats, at least 15 in all, each 10-60 km long, 20-30 km wide (126,000 $\mathrm{km}^{2}$ area) and thickness up to $5 \mathrm{~m}$, travel > 1 $\mathrm{km} \mathrm{y}^{-1}$ from Brazil to eastern Venezuela (Gardel and Gratiot 2005). The mudflats are associated with space- and time-varying depositional 'bank' phases and erosional 'inter-bank' phases, which lead to either rapid settlement or destruction of mangroves, depending on the level of accretion or erosion of the intertidal fringe. The specific characteristics of each sedimentary area depend on the tidal range and swells. These induce strong sedimentation rates of homogeneous fluid mud, often several meters thick, while tides induce repeated sedimentation of several centimetres, depending on sediment availability (Gensac et al. 2015).

Although the dynamics of mudbanks along the Guianan coast have been studied extensively in recent years, data on infaunal biodiversity, community structure, and thus food web function is lacking for this highly dynamic and unstable environment. Macrofauna, sometimes defined as metazoans retained by a sieve with a 1-mm square mesh opening (Mare 1942; Bachelet 1990), is usually a major component of the total biomass and plays a central role in the functioning of these ecosystems (Gray and Elliot 2009). Surprisingly, only two studies on macrofaunal biodiversity and abundance have been conducted in this region over the last 30 years. The first provided data on the main OTU occurring along Suriname's coast, but lacked species-level identification for many organisms (Swennen et al. 1982). The second study was conducted in the Kaw Estuary in French Guiana, but had only a limited number of sampling stations (Clavier 1999). Despite these shortcomings, both studies found low 
macrofaunal diversity and the dominance of very few taxa such as tanaidaceans, although densities were highly variable depending on the habitat sampled. However, a recent study on the structure of meiofauna in French Guiana and Suriname mudflats indicates a very productive zone with a thick biofilm of microphytobenthos and prokaryotes (up to $1 \mathrm{~mm}$ thick. Gensac et al. 2015), coupled with a high abundance and biomass of meiofauna, mainly dominated by nematodes (Dupuy et al. 2015). Local sediment granulometry and organic matter content appeared to drive the size structure and functional characteristics of nematodes. Despite the high instability of mudflats in this region, chlorophyll $a$, biomass and meiofauna abundance always tend to be higher than in other areas such as temperate European or tropical Australian and Vietnamese mudflats (Dupuy et al. 2015). Consequently, the question arises if this biofilm could be essential in food web function through direct trophic links with the macrofauna, and thus support a rich benthic community.

In the present study, sediment characteristics, and richness, diversity, and density of the benthic macrofaunal communities are documented at three sites along the coast of French Guiana and Suriname. It is hypothesized that differences in these characteristics are determined by the relative distance from the Amazon Delta, the sediment source for these coastal mudbanks. It is also postulated that because of the highly dynamic nature of mudbanks, richness and diversity of macrofaunal benthic communities will differ from other tropical or temperate mudflats. Biometric measures (individual size/length) of macrofaunal organisms are documented in this study based on the premise that highly dynamic conditions along the Guianan coast limit the occurrence of large-bodied macrofaunal species. Consequently, it is expected that findings of the present study will support the theory of a complex diversity-stability relationship, in which high environmental variability results in fewer species and greater evenness (Lehmann-Ziebarth and Ives 2006).

\section{Methods}

\section{Study sites}

The study was conducted at one site in the Awala-Yalimapo region of western French Guiana, near the mouth of the Maroni River $\left(05^{\circ} 44^{\prime} 44^{\prime \prime N}\right.$; 53 $\left.55^{\circ} 36^{\prime \prime} \mathrm{W}\right)$, and at two sites in Suriname, Warappa Kreek, Commewijne district (05'59'33"N; 54 55'50"W) and Bigi Pan, Nickerie District $\left(05^{\circ} 59^{\prime} 09^{\prime \prime N}\right.$; 56 53'03"W), near the mouth of the Corentyne River (Fig. 1). The sites 
are located 800, 920 and 1,140 km, respectively, from the Amazon Delta. Tides at all three sites are semidiurnal with a range of $0.8-2.9 \mathrm{~m}$. The Awala site was at the leading edge of a mudbank composed of very fluid mud, and below a bare sandy beach. The site was adjacent to an area with young mangroves trees on somewhat consolidated mud. The Bigi Pan and Warappa sites were closer to the trailing edges of two different mudbanks and characterized by an erosive area (consolidated muds with micro-cliffs) crowded with dead trees lying in the mud, situated below a sandy shore that was partially colonized by adult mangrove trees. Sampling stations were below this erosive area.

\section{Sampling strategy}

All intertidal stations were sampled in April 2012 (wet season). At each site, five to six stations close to the shore were visited on foot. They were positioned a priori using GPS, such that adjacent stations were separated by a 200-300 m distance. However, given the difficulty of sampling the soft sediment at low tide, and of dealing with the fast moving ebbing or rising tides at high tide, actual stations were selected 5-15 $\mathrm{m}$ from the shore depending on mudflat conditions at the time of sampling. This explains variations in the distance between stations (Fig. 1). The mean distance among stations was $285 \pm 20 \mathrm{~m}$ (standard deviation, SD) at Awala, $340 \pm 105 \mathrm{~m}$ (W10-W14) at Warappa and $245 \pm 90 \mathrm{~m}$ at Bigi Pan.

Additionally, the availability of a boat at Warappa Kreek allowed sampling a 2-km intertidal transect perpendicular to the shore (Fig. 1). There were nine stations on this transect, eight sampled by boat (W1-W8), and one (W9) sampled on foot. The mean distance ( \pm SD) between stations was $260 \pm 17 \mathrm{~m}$ (W1-W9).

For each nearshore station, six replicate sediment samples were haphazardly collected, avoiding trampling the area, with a plastic corer $(15-\mathrm{cm}$ internal diameter) to a depth of 20 $\mathrm{cm}$. For the intertidal transect at Warappa, a metal vacuum corer with a $10-\mathrm{cm}$ internal diameter was used, and two cores were combined into one sample. There were six of these combined samples per station (Bocher et al. 2007). Sampling from a boat or on foot yields identical estimates (Kraan et al. 2007). All samples were sieved through a 0.5-mm mesh and organisms retained on the sieve were fixed in $70 \%$ ethanol.

\section{Sediment characteristics}

At every station, a sediment sample was taken to a maximum depth of $4-5 \mathrm{~cm}$ to evaluate grain size. The sediment grain size was characterized using a Malvern Mastersizer 2000 
(Malvern Instruments Ltd, U.K.) (size range: 0.02-2000 $\mu \mathrm{m}$ ). Results were computed using Gradistat version 4.0 software and expressed as percentages of different grain size classes and geometric mean grain size. The different size classes given by Gradistat were grouped into four main categories: silt and clay $(<63 \mu \mathrm{m})$, fine sand $(63 \mu \mathrm{m}-250 \mu \mathrm{m})$, medium sand $(250$ $\mu \mathrm{m}-500 \mu \mathrm{m})$ and coarse sand $(500 \mu \mathrm{m}-2000 \mu \mathrm{m})$.

\section{Macrofaunal sorting and species identification}

In the laboratory, samples were stained with the vital stain Rose Bengal to improve sorting and washed on a $0.5-\mathrm{mm}$ mesh sieve. All individuals were first sorted into major taxonomic groups (e.g., annelids, tanaidaceans, crustaceans other than tanaidaceans, molluscs and insects). In several cases, samples containing a high abundance of tanaidaceans were further subdivided using a Motoda box to estimate the total abundance of tanaids (Motoda 1959). Macroinvertebrates were identified using a Leica MZ205C stereomicroscope and, when necessary, an Olympus BH-2 compound microscope. Whenever possible, organisms were identified to the species level. Unfortunately, infaunal taxonomic literature is limited for this poorly studied, biogeographical region. To deal with the issue of identification to levels of species, genus, family or higher, the term OTU (Operational Taxonomic Units) is used in the present study. Faunal data available for statistical analyses were richness (i.e., number of OTU recorded) and density. These metrics were used to compute the occurrence (\% of occurrence in stations of the whole data set or of a cluster where the OTU was recorded), frequencies (\% of individuals of a given OTU out of all individuals recorded across all stations or for a cluster of stations), and the Shannon diversity index ((log 2) H'. Shannon and Weaver 1949). Biometric data (individual body length) were acquired using Leica stereomicroscope software (LAS).

\section{Statistical analyses}

One-way analysis of variance (ANOVA) and post-hoc Dunn's multiple comparison tests were performed on geometric mean grain size among sites (Awala, Bigi Pan, Warappa nearshore stations and Warappa offshore transect). Normality of the data was evaluated using a ShapiroWilk test. Taxonomic richness $(\mathrm{S})$, density $(\mathrm{N})$ and Shannon diversity index (H') data were not normally distributed (Shapiro-Wilk test: $P<0.05$ ), so Kruskal-Wallis one-way ANOVA on ranks was used to test for differences in each variable ( $\mathrm{S}, \mathrm{N}$ and $\left.\mathrm{H}^{\prime}\right)$ among sites. Subsequently, post-hoc Dunn's pairwise multiple comparison tests were performed for the three variables to allow a comparison among sites. 
Community statistical analyses were performed using Primer 6 software (Clarke and Gorley 2006). Hierarchical clustering and multidimensional scaling (MDS) of the stations were obtained from a Bray-Curtis similarity matrix computed with fourth root-transformed species densities. The SIMPROF routine ('SIMilarity PROFile' permutation tests) was used to identify genuine clusters (at a 5\% significance level) to better define groups of stations using hierarchical clustering. The SIMPER routine (SIMilarity PERcentages) was performed to answer the questions of which OTU structured the clusters (90\% cutoff for low contributions) and which contributed to dissimilarity. It was considered that a "good" discriminating OTU shows a ratio of dissimilarity to standard deviation between clusters (Diss/SD) > 1.5 (Wildsmith et al. 2009).

\section{Results}

\section{Sediment characteristics}

No obvious granulometric gradient was detected among the three study sites based on their distance from the Amazon Delta. The intertidal substrate was devoid of macro-vegetation and was mostly comprised of fine silt and clay (Table 1; ESM 1) at every site. Thus, mud accounted for $>99 \%$ of the total sediment in all nearshore stations of Awala and Warappa. In Bigi Pan, sand accounted for almost 10\% (B1, B5 and B6), with mud content ranging between 89.3 and $98.6 \%$. On the Warappa transect, at stations W1 to W6, sand percentages were higher, reaching almost $25 \%$ at the most remote station (W1). Transect stations closest to the coast (W7 and W8) had a similar mud content to nearshore stations. Mean grain size was consistently $<10 \mu \mathrm{m}$ for all nearshore stations (Table 1). Values differed significantly among sites (one-way ANOVA, $\mathrm{F}=17.236$, $\mathrm{df}=3, P<0.001$ ). Post-hoc Dunn's multiple comparison tests indicated that the mean grain size for Warappa transect stations was significantly different from Awala and Warappa nearshore stations $(P<0.05)$, but not from Bigi Pan $(P>0.05)$.

\section{Richness}

Thirty-eight OTUs were identified across the three study sites (Table 2), 16 at Awala, 28 at Warappa (22 offshore, 11 nearshore) and 14 at Bigi Pan. Among these OTU, 50\% were identified to the species level and another $18 \%$ to genus. Among the 38 OTU, 7 were Crustacea, 13 Polychaeta and 13 Mollusca. Two species showed an occurrence $>50 \%$ and 
were widely distributed among sites (Table 2): the tanaid Halmyrapseudes spaansi was present at every station and the polychaete Sigambra grubii was recorded at $76 \%$ of the stations, including $100 \%$ of the nearshore stations. Other OTU found at the three sites were the tanaid Discapseudes surinamensis (Crustacea: Tanaidacea), the bivalve Macoma constricta (Mollusca: Bivalva) and nemerteans. Ten OTU were recorded at two sites and 22 were sampled at only one station (three in Awala, 16 in Warappa and three in Bigi Pan), out of which 12 were encountered at only one station (Table 2) and 13 along the Warappa transect. The highfin goby Gobionellus oceanicus was the only fish species found residing in mud during low tide, where it inhabits U-shaped burrows (Puyo 1949 in Pezold 2004; Lefrançois, University of La Rochelle, pers. com.). This species was mainly recorded at Awala, but was also found at Warappa. Larvae of long-legged flies (Dolichopodidae) were found in Awala and at all Bigi Pan stations.

Mean taxonomic richness differed significantly among sites (Kruskal-Wallis one-way ANOVA on ranks, $\mathrm{H}=14.201$, $\mathrm{df}=3, P=0.003$ ). However, a post-hoc Dunn's multiple comparison test showed that mean taxonomic richness differed significantly only between Bigi Pan and both Warappa groups $(P<0.05)$. At the site scale, total richness by station was 3-11 OTU in Awala (Table 2), and mean richness (Fig. 2A) ranged from 1.3 (A2) to 5.8 OTU (A5). At Warappa stations, total richness ranged from 2 to 11 OTU. Whereas 6-11 OTU were recorded at transect stations, total richness was lower at nearshore stations with 2-7 OTU (Table 2). This difference, however, was not supported by mean richness, which ranged from 2.5 to 3.0 OTU per station for the whole site (Fig. 2A) (post-hoc Dunn's pairwise multiple comparison test between Warappa transect and nearshore stations: $P>0.05)$. At Bigi Pan, total and mean richness (7-9 OTU and 4.0-5.2 OTU, respectively) were homogenous and among the highest recorded in the present study.

\section{Densities and diversities}

Considering all OTU values by station, individual densities ( \pm SD) ranged widely from $72 \pm$ 56 ind. $\mathrm{m}^{-2}$ at $\mathrm{A} 2$, up to $31,000 \pm 27,000$ ind. $\mathrm{m}^{-2}$ at B3 (Fig. $2 \mathrm{~B}$ ), which contributed to the significant differences recorded among sites (Kruskal-Wallis one-way ANOVA on ranks, $\mathrm{H}=$ 20.072, df $=3, P<0.001$ ). A post-hoc test identified differences among Bigi Pan and both Awala and Warappa transect stations, as well as between Warappa nearshore and transect stations $(P>0.05)$, but not between Warappa nearshore stations and Awala $(P>0.05)$. 
Lowest values (100-300 ind. $\mathrm{m}^{-2}$ ) were recorded at Awala and at the most distant stations along the offshore transect. This contrasted with densities recorded, up to ca. 11,000 ind. $\mathrm{m}^{-2}$, at nearshore Warappa stations, and up to ca. 31,000 ind. $\mathrm{m}^{-2}$ at Bigi Pan, where densities were always $>10,000$ ind. $\mathrm{m}^{-2}$. The W8 station was singular within the offshore transect since it presented a density comparable to nearshore stations (Fig. 2B). No significant difference was found, however, between densities at Bigi Pan and Warappa nearshore stations (Dunn's post-hoc test, $P>0.05$ ). Indeed, some stations at Bigi Pan showed high variability, with replicates ranging by two orders of magnitude, from 484 ind. $\mathrm{m}^{-2}$ to ca. 40,000 ind. $\mathrm{m}^{-2}$.

In this study, only three species represented $>1 \%$ of the total of individuals counted per station: Halmyrapseudes spaansi (84.5\%), Sigambra grubii (7.9\%) and Discapseudes surinamensis (5.3\%). Each of the remaining OTU accounted for $<0.4 \%$ of all individuals counted.

Taxonomic diversity (Shannon index H'), which reflects taxonomic richness and the relative densities of the OTU, differed among stations within sites, ranging from twofold in Bigi Pan up to tenfold in Awala. Thus, mean $H^{\prime} \pm$ SD ranged from $0.17 \pm 0.41$ to $1.74 \pm 0.30$ (Fig. 2C).

\section{Size of macrobenthic organisms}

An important common characteristic of the macrobenthic community in intertidal mudflats of the Guianas coast was the small size of most individuals. Among the three most common OTU, no individuals were $>13 \mathrm{~mm}$ long. Mean length $( \pm \mathrm{SD})$ of $H$. spaansi was $3.8 \pm 1.0$ $\mathrm{mm}(1.7-8.6 \mathrm{~mm}, n=653), 7.8 \pm 2.8 \mathrm{~mm}(2.5-12.9 \mathrm{~mm}, n=146)$ for $D$. surinamensis and $6.6 \pm 1.7 \mathrm{~mm}(2.1-13.0 \mathrm{~mm}, n=40)$ for the polychaete $S$. grubii. The shell length (greatest antero-posterior length) of all bivalves was 2.1 to $8.4 \mathrm{~mm}$, with the exception of Macoma constricta $(11.2 \pm 5.1 \mathrm{~mm},(n=6)$ and Tagelus plebeius, with two individuals with a shell length of 11.9 and $12.7 \mathrm{~mm}$. The most common gastropods, Assiminea succinea and Cylichnella bidentata, had a mean shell height $( \pm \mathrm{SD})$ of $1.3 \pm 0.3 \mathrm{~mm}(n=54)$ and of $2.1 \pm$ $0.4 \mathrm{~mm}(n=15)$, respectively. Few annelids exceeded $20 \mathrm{~mm}$. The largest organisms was the fish, G. oceanicus, with a mean length of $14.3 \pm 5.1 \mathrm{~mm}(n=28)$, and maximum length of $32.9 \mathrm{~mm}$.

\section{Macrofaunal assemblages}


Hierarchical clustering of stations using SIMPROF and MDS revealed four clusters (Fig. 3; ESM 2): Awala (A), Bigi Pan (B), Warappa nearshore (Wn) and Warappa offshore (Wo); and two outliers: A2 and W7. All were organized in two main clusters, with the offshore Warappa stations (W1-W6) found to be clearly different from all inshore stations. The exception was W8, a priori considered an offshore station, which appeared similar to the inshore Warappa stations, and the outlier W7. In general, the four clusters (A, B, Wn \& Wo) grouped stations from the same site. Station W7 was distinct from both nearshore cluster (A, B and Wn) and Wo, remaining in an intermediate position more closely associated with the Wo stations. Station A2 was in the nearshore stations cluster, but segregated from the three assemblages A, $\mathrm{B}$ and $\mathrm{Wn}$.

The main OTU contributing to similarity within site clusters are shown in Table 3 (SIMPER results). The tanaid Halmyrapseudes spaansi appeared to be the main contributor, especially at nearshore stations in Warappa and Bigi Pan. The polychaete Sigambra grubii characterized nearshore assemblages (A, B, Wn). Moreover, these two species were responsible for $>90 \%$ of the similarity within the Wn cluster. The remaining OTU in Table 3 were typical of different clusters. Thus, the gastropod Assiminea succinea, the fish Gobionellus oceanicus and polychaete Streblospio gynobranchiata distinguished cluster A. Cluster B was distinguished by the tanaid Discapseudes surinamensis, the capitellid polychaete Heteromastus sp. and the Dolichopodidae insect family. The offshore cluster (Wo) was typified by an unidentified lumbrinerid polychaete (cf. Abyssoninoe sp. likely to be an undescribed species, Carrera-Parra, El Colegio de la Frontera Sur, pers. com.), the gastropod Cylichnella bidentata, the polychaetes Alitta sp., Mediomastus sp. and an unidentified orbiniid polychaete (cf. Scoloplos sp.).

Concerning the outliers (A2 and W7), OTU frequencies $(100 * \mathrm{Ni} / \mathrm{Nt}$, where $\mathrm{Ni}$ is the density of OTU $\mathrm{i}$ and $\mathrm{Nt}$ is the total density at the station) were used to describe the faunal community structure (Table 3). Thus, A2 was mainly characterized by $S$. grubii and $H$. spaansi, and thus explains its inclusion in the nearshore station cluster. In the W7 cluster, the most important species were the capitellid polychaetes (other than Mediomastus sp. and Heteromastus sp.), Mediomastus sp. as well as oligochaetes. Species characteristic of other clusters, such as H. spaansi and S. grubii (nearshore clusters), D. surinamensis (B) and the Lumbrineridae species (Wo), that were also present in W7, also likely contributed to explain W7 intermediate status. 
The OTU mainly responsible for similarities within clusters were the main OTU allowing discrimination among clusters (Table 4). However, distinguishing OTU could be split into two categories: 'typical' OTU, mainly, if not exclusively, recorded from one cluster (e.g., A. succinea, Alitta sp., C. bidentata, D. surinamensis, Dolichopodidae, G. oceanicus, Heteromastus sp., Lumbrineridae; ESM 3) and 'ubiquitous' OTU (e.g., H. spaansi), widely distributed throughout the study area and whose contributions to dissimilarities were likely due to differences in their distribution (densities and density variability) among stations within clusters (ESM 3). Thus, S. grubii was both a 'typical' species and a 'ubiquitous' species in the nearshore clusters.

\section{Discussion}

The 1,500-km coast between the Amazon and Orinoco River deltas is a unique system, comprised of an array of migrating, shifting mudbanks (Anthony et al. 2010). The biological communities in these mudflats are poorly known. Previous studies dealing with intertidal macrofaunal communities in Suriname (Swennen et al. 1982) and French Guiana (Clavier 1999) were restricted to a few mudflat sites and limited in taxonomic resolution, focusing only on major taxa. The present study was thus constrained by the lack of previous taxonomic work in the region, given the few available studies and the nature of the substrate compared to the east coast of the Amazon estuary (Kober and Barlein 2006; Braga et al. 2011; Venturini et al. 2011; Botter-Carvalho et al. 2014). It is thus likely that some individuals sampled belong to undescribed species (e.g., within the Lumbrineridae). Among the 19 identified species in the present study, 14 were previously recorded from the Brazilian coast east of the Amazon Estuary, whereas 13 had been previously observed in the Caribbean Basin. Only one species, the tanaid Discapseudes surinamensis, has never been previously collected outside the study area (Bacescu and Gutu 1975).

The present study allowed identification of two distinct communities whose differences depend on the level in the intertidal (mean high water vs mean medium and low water) rather than the distance from the Amazon estuary as originally hypothesized. The nearshore communities of the three sites fit partially with descriptions already reported by Clavier (1999) and Swennen et al. (1982), as tanaid species are highly abundant and dominant taxa. Thus, Halmyrapseudes spaansi and D. surinamensis reached densities of up to 73,000 ind. $\mathrm{m}^{-2}$ and 8,000 ind. $\mathrm{m}^{-2}$, respectively, in the present study. Both previous studies reported 
dominance of tanaids at most of the sampling sites, i.e., up to 67,000 ind. $\mathrm{m}^{-2}$ in the Kaw Estuary, French Guiana, although the species was not identified (Clavier 1999), and mean abundances of 16,000 ind. $\mathrm{m}^{-2}$ for $H$. spaansi and 20,500 ind. $\mathrm{m}^{-2}$ for D. surinamensis in a coastal lagoon near Krofajapasi, Suriname (Swennen et al. 1982). Halmyrapseudes spaansi and S. grubii, which are widely distributed in the studied area, were the main species in nearshore communities in the present study. Sigambra grubii is common along the coast of Brazil in different soft bottom habitats (Lana et al. 1997; Venturini et al. 2011; Braga et al. 2011; Botter-Carvalho et al. 2014). This ubiquitous species seems enough of a generalist to exploit the highly unstable mudflats of the coast of Guiana. These two dominant species can locally make up $>90 \%$ of the observed densities (Warappa), although $S$. grubii seems to be typical of nearshore communities as it was almost completely absent from the offshore intertidal community at Warappa. This dominance by a very few species and the low taxonomic richness, explain the low Shannon diversity indices values for the nearshore macrofaunal communities here reported. Furthermore, each site appeared to have its own characteristic density ratios between the two dominant species as well as a characteristic OTU. Indeed, the singularity of the Warappa nearshore community was precisely in the huge contribution of $H$. spaansi and S. grubii to the exclusion of most other OTU, whereas Awala and Bigi Pan were more diverse and differed in their site-specific OTU. These local differences cannot be explained by sediment characteristics, as there was no obvious gradient at mean high water among the sites. Consequently, as reported by Dupuy et al. (2015) for meiofauna, differences in macrofaunal assemblages are mainly attributed to local conditions, especially the migration stage of banks, at the scale examined in the present study. The Awala stations were located at the leading edge of a mudbank, characterized by very fluid mud, and were close to a mangrove colonization area, whereas stations at Bigi Pan and Warappa were closer to the trailing edges of two mudbanks characterized by an erosive regime and mature mangrove trees. A complex interaction of local physical factors could explain the differences in macrofaunal benthic assemblages among sites, but unfortunately, it was not possible to measure these characteristics, except for sediment grain size.

The mid- and lower tidal level community at Warappa was not described by Swennen et al. (1982) and Clavier (1999), and thus appears to be unknown prior to this study. This sparse, but diverse community comprises $>50 \%$ of all macrobenthic OTU recorded (22 out of 38), with more than half found to be site-specific (13). Halmyrapseudes spaansi was present, but in low densities, and, S. grubii almost absent. A lumbrinerid (cf. Abyssoninoe sp.), 
together with Alitta sp. and the gastropod Cylichnella bidentata dominate this community. Sediment granulometric composition may also partially explain the difference in taxonomic faunal composition between nearshore and offshore stations. Most notably, the offshore sediments at Warappa had a higher proportion of coarse sand. Another possible explanation for the differences between the offshore and nearshore stations might be a higher nutrient supply inshore due to the proximity of sources of estuarine and mangrove leaf decomposition. The subtidal extent of the offshore community at Warappa is unknown.

Low diversity seems to be a major feature of bare intertidal mudflats. Previous studies on tropical mudflats showed that $10-32 \%$ of the species account for 80 or $95 \%$ of the individuals reported (Vargas 1987; Wolff et al. 1993; Dittmann 1995). In the present study, $H$. spaansi constituted $84 \%$ of all individuals sampled. Thus, tanaids $H$. spaansi, widely distributed, $D$. surinamensis, locally very abundant, and probably the tanaid Monokalliapseudes guianae that prefers estuarine conditions (Drumm et al. 2015), clearly constitute the major component of the macrobenthic communities along the 1,500 km-length of Guiana's coast. A fourth tanaid species, Discapseudes holthuisi, described from Suriname by Bacescu and Gutu (1975), was not recorded in the present study. Tanaids might occupy the same ecological niche and importance as the well-studied amphipod Corophium volutator in temperate systems. In bare mudflats of the Bay of Fundy and Europe, $C$. volutator can occur at densities of 10,000s ind. $\mathrm{m}^{-2}$ (Hawkins 1985, Murdoch et al. 1986, Peer et al.1986, Møller and Riisgård 2006). Like corophids (Meadows and Reid 1966, Peer et al. 1986, Møller and Riisgård 2006), tanaids live in burrows (Bacescu and Gutu 1975) and are believed to be surface deposit-feeders that mostly feed on biofilms they collect by scraping the mud surface with their long appendages.

Conversely, some differences between Guiana's mudflats and those in temperate zones have also been identified. Thus, although 580 species of marine molluscs have been recorded from the Guianas' coast (Massemin et al. 2009), only 13 species (seven bivalves and six gastropods) were recorded in the present study. They globally show very low occurrences and densities and would not contribute significantly to the total biomass of macrofauna, since they are typically small. Most of the 580 molluscan species are restricted to subtidal and deeper levels, and few species seem able to live on the very soft and dynamic substrate of tidal mudflats. Only the gastropods Assiminea succinea at Awala and Cylichnella bidentata in offshore Warappa were sufficiently abundant to contribute significantly to the local community structure. None of them, however, reached abundances comparable to those of the 
widespread gastropod Hydrobia ulvae, considered the most common deposit-feeder in European intertidal mudflat communities (Newell 1979), where they can reach several thousands of individuals per $\mathrm{m}^{2}$ (Dekker 1989; Bocher et al. 2007).

Insects are rarely included in studies of marine coastal macrofauna. However, they can be major components of coastal infaunal communities in low salinity areas such as the Baltic Sea (Hummel et al. 2016). The long-legged flies (Dolichopodidae) are known to include marine representatives (Hinton, 1976) and can thus be considered a component of infaunal communities during larval stages. In the present study, they were recorded at several stations, sometimes with relatively high densities (up to 700 ind. $\mathrm{m}^{-2}$ ). Adults were also observed at the surface of the mud at low tide and could be part of the mudflat food web by feeding on the surface biofilm (Pollet and Brooks 2008).

The highfin goby, Gobionellus oceanicus, was present in most Awala samples. Like insect larvae, fishes are not usually included in studies of benthic macrofaunal communities since they are mobile, and not necessarily well sampled by benthic cores. This estuarine resident (Andrade-Tubino et al. 2008) is widely distributed from the state of Virginia in the United States to southern Brazil, and occurs in soft bottoms along coasts and estuaries (Robins et al. 1999). At low tide, G. oceanicus individuals remain in water-filled burrows (Ushaped in Awala) that they excavate in the mud (Puyo 1949 in Pezold 2004; Lefrançois, University of La Rochelle, pers. com.). In the present study, this fish species was patchily distributed at low tide, but sometimes reached densities up to 50 ind. $\mathrm{m}^{-2}$. The individuals collected were $<33 \mathrm{~mm}$ in length and were likely juvenile that depend on this habitat during early, nursery stages (Wyanski and Targett 2000; Gomes and Bonecker 2014; Gomes et al. 2014). Although the species is considered to be a detritivore (Vasconcelos Filho et al. 2003), there is evidence from field observations and stomach contents that it can also feed on tanaids (Lefrançois, unpublished results). Thus, densities of the benthic goby could either be related to the importance of the surface biofilm as a food source or/and to high densities of tanaids as an abundant food source.

The highly dynamic conditions of the intertidal mudflats of the Guianas, related to the high variability of environmental factors (e.g., high physical forcing, and large variable freshwater input), should limit settlement success and the adaptive capacities especially of large-sized species in very soft mobile mud. A previous study on the meiofauna at the same sites documented a very high abundance of these small organisms, especially nematodes, 
which was higher than that reported in other areas worldwide (Dupuy et al. 2015). However, the production of these mudflat ecosystems is expected to be very high and largely subject to export. Based on the results of the present study, future research should focus on the resilience capacity, via shifts in functional benthic groups due to adaptation or resistance to local stress conditions, especially strong physical instability, of all community components of the mudflat ecosystem.

\section{Acknowledgments}

This study was funded by the University of La Rochelle, the CNRS and the National Fish and Wildlife Foundation via the New Jersey Audubon Society. The authors thank Sophie Maillé from GEPOG in French Guiana for technical support, Thierry Guyot (LIENSs laboratory) for the map, Michel Le Duff (IUEM UBO) for his very valuable help with mollusk taxonomy and The Microscopic Logistical Department of the Laboratory LIENSs. We are also grateful to the two anonymous referees for their very valuable comments and suggestions.

\section{References}

Allison, M.A., and M.T. Lee. 2004. Sediment exchange between Amazon mudbanks and shore-fringing mangroves in French Guiana. Marine Geology 208: 169-190.

Allison, M.A., M.T Lee., A.S. Ogston, and R.C. Aller. 2000. Origin of Amazon mudbanks along the northeastern coast of South America. Marine Geology 163: 241-256.

Andrade-Tubino, M. F., A.L. Ribeiro and M. Vianna. 2008. Organização espaço-temporal das ictiocenoses demersais nos ecossistemas estuarinos brasileiros: uma síntese. Oecologia Brasiliensis 12, 640-661.

Anthony, E.J., A. Gardel, N. Gratiot, C. Proisy, M.A. Allison, F. Dolique, and F. Fromard. 2010. The Amazon-influenced muddy coast of South America: A review of mud-bank shoreline interactions. Earth-Science Reviews 103: 99-121.

Augustinus, P.G.E.F. 1978. The changing shoreline of Suriname (South America). Ph.D. Thesis, University Utrecht. 232 pp.

Bacescu, M., and M. Gutu. 1975. A new genus (Discapseudes ng) and three new species of Apseudidae (Crustacea, Tanaidacea) from the northeastern coast of South America. Zoologische Mededelingen 49: 95-113.

Bachelet, G. 1990. The choice of a sieving mesh size in the quantitative assessment of marine macrobenthos: a necessary compromise between aims and constraints. Marine Environmental Research 30: 21-35. 
Baltzer, F., M. Allison, and F. Fromard. 2004. Material exchange between the continental shelf and mangrove-fringed coasts with special reference to the Amazonian-Guianas coast. Marine Geology 208: 115-126.

Bocher, P., T. Piersma, A. Dekinga, C. Kraan, M.G.Yates, T. Guyot, E.O. Folmer, and G. Radenac. 2007. Site- and species-specific distribution patterns of molluscs at five intertidal soft-sediment areas in northwest Europe during a single winter. Marine Biology 151: 577-594.

Botter-Carvalho, M.L., P.V. Carvalho, A.P.M. Valença, and P.J. Santos. 2014. Estuarine macrofauna responses to continuous in situ nutrient addition on a tropical mudflat. Marine Pollution Bulletin 83: 214-223.

Braga, C.F., V.F. Monteiro, J.S. Rosa-Filho, and C.R. Beasley. 2011. Benthic macroinfaunal assemblages associated with Amazonian saltmarshes. Wetlands Ecology and Management 19: 257-272.

Clarke, K.R., and R.N. Gorley. 2006. PRIMER version 6: user manual/tutorial.

Clavier, J. 1999. Macrobenthos de petite taille dans les vasières et la mangrove de Kaw: document de travail. Pnoc-guyane - action de recherche mangroves. IRD Bretagne. $11 \mathrm{pp}$.

Dekker, R. 1989. The macrozoobenthos of the subtidal western Dutch Wadden Sea. I. Biomass and species richness. Netherlands Journal of Sea Research 23: 57-68.

Dittmann, S. 1995. Benthos structure on tropical tidal flats of Australia. Helgoländer Meeresuntersuchungen 49: 539-551.

Drumm, D.T., J. Jourde, and P. Bocher. 2015. A new species of the genus Monokalliapseudes (Crustacea: Tanaidacea: Kalliapseudidae) from French Guiana. Proceedings of the Biological Society of Washington 128: 86-97.

Dupuy, C., T.H. Nguyen, D. Mizrahi, J. Jourde, M. Bréret, H. Agogué, L. Beaugeard, and P. Bocher. 2015. Structure and functional characteristics of the meiofauna community in highly unstable intertidal mudbanks in Suriname and French Guiana (north Atlantic coast of South America). Continental Shelf Research 110: 39-47.

Eisma, D., P. Augustinus, and C. Alexander. 1991. Recent and subrecent changes in the dispersal of Amazon mud. Netherlands Journal of Sea Research 28: 181-192.

Gardel, A., and N. Gratiot. 2005. A satellite image-based method for estimating rates of mud bank migration, French Guiana, South America. Journal of Coastal Research 21: 720 728.

Gensac, E., A. Gardel, S. Lesourd, and L. Brutier. 2015. Morphodynamic evolution of an intertidal mudflat under the influence of Amazon sediment supply -Kourou mud bank, French Guiana, South America. Estuarine, Coastal and Shelf Science 158: 53-62.

Gomes, E.A.P., and A.C. Bonecker. 2014. Structure and dynamics of Gobiidae larvae (Teleostei, Perciformes) in a tropical estuary: seasonal relationships with tidal cycles. Journal of the Marine Biological Association of the United Kingdom 94: 1557-1568. 
Gomes, E.A.P., P.N. Campos, and A.C. Bonecker. 2014. Occurrence of Gobiidae larvae in a tropical Brazilian estuary, with particular emphasis on the use of size classes to categorize species guilds. Journal of Fish Biology 84: 996-1013.

Gratiot, N., A. Gardel, and E.J. Anthony. 2007. Trade-wind waves and mud dynamics on the French Guiana coast, South America: input from ERA-40 wave data and field investigations. Marine Geology 236: 15-26.

Gray, J.S., and M. Elliott. 2009. Ecology of marine sediments: from science to management. Oxford University Press.

Hawkins, C.M. 1985. Population carbon budgets and the importance of the amphipod Corophium volutator in the carbon transfer on a Cumberland Basin mudflat, upper Bay of Fundy, Canada. Netherlands Journal of Sea Research 19: 165-176.

Hinton, H.E. 1976. Respiratory adaptations of marine insects. In Marine insects, ed. L. Cheng. Amsterdam: North-Holland Publ. Co.

Hummel, H., P. Van Avesaath, S. Wijnhoven, L. Kleine-Schaars, S. Degraer, F. Kerckhof, N. Bojanic, S. Skejic, O. Vidjak, M. Rousou, H. Orav-Kotta, J. Kotta, J. Jourde, M.L. Pedrotti, J.C. Leclerc, N. Simon, F. Rigaut-Jalabert, G. Bachelet, N. Lavesque, C. Arvanitidis, C. Pavloudi, S. Faulwetter, T. Crowe, J. Coughlan, L. Benedetti-Cecchi, M. Dal Bello, P. Magni, S. Como, S. Coppa, A. Ikauniece, T. Ruginis, E. Jankowska, J.M. Weslawski, J. Warzocha, S. Gromisz, B. Witalis, T. Silva, P. Ribeiro, V.K. Fernandes De Matos, I. Sousa-Pinto, P. Veiga, J. Troncoso, X. Guinda, J.A. Juanes De La Pena, A. Puente, F. Espinosa, A. Pérez-Ruzafa, M. Frost, C.L. Mcneill, O. Peleg, and G. Rilov. 2016. Geographic patterns of biodiversity in European coastal marine benthos. Journal of the Marine Biological Association of the United Kingdom. Doi: $10.1017 / \mathrm{S} 0025315416001119$.

Kober, K., and F. Bairlein. 2006. Shorebirds of the Bragantinian Peninsula 1. Prey availability and shorebird consumption at a tropical site in Northern Brazil. Ornitologia Neotropical 17: 531-54.

Kraan, C., T. Piersma, A. Dekinga, A. Koolhaas and J. Van der Meer. 2007. Dredging for edible cockles (Cerastoderma edule) on intertidal flats: short-term consequences of fisher patch-choice decisions for target and non-target benthic fauna. ICES Journal of Marine Science: Journal du Conseil 64: 1735-1742.

Lana, P.C., E.C. Couto, and M.V. Almeida. 1997. Polychaete distribution and abundance in intertidal flats of Paranaguá Bay (SE Brazil). Bulletin of Marine Science 60: 433-442.

Lehmann-Ziebarth, N., and A.R. Ives. 2006. The structure and stability of model ecosystems assembled in a variable environment. Oikos 114: 451-464.

Mare, M.F. 1942. A study of a marine benthic community with special reference to the microorganisms. Journal of the Marine Biological Association of the United Kingdom 25: 517-54.

Martinez, J.-M., J.-L. Guyot, N. Filizola, and F. Sondag. 2009. Increase in suspended sediment discharge of the Amazon River assessed by monitoring network and satellite data. Catena 79: 257-264. 
Massemin, D., D. Lamy, J.-P. Pointier, and O. Gargominy. 2009. Coquillages et escargots de Guyane. Seashells and snails from French Guiana. Biotope, Mèze (Collection Parthénope). Museum National d'Histoire Naturelle, Paris.

Meadows, P.S., and A. Reid. 1966. The behaviour of Corophium volutator (Crustacea: Amphipoda). Journal of Zoology. 150: 387-399.

Møller, L.F., Riisgård, H.U., 2006. Filter feeding in the burrowing amphipod Corophium volutator. Marine Ecology Progress Series 322, 213-224.

Motoda, S. 1959. Devices of simple plankton apparatus. Memoire of Fisheries Faculty, Hokkaido University, Vol.7, pp.73-94.

Murdoch, M.H., F. Bärlocher and M.L. Laltoo. 1986. Population dynamics and nutrition of Corophium volutator (Pallas) in the Cumberland Basin (Bay of Fundy). Journal of Experimental Marine Biology and Ecology 103: 235-249.

Newell, R. 1979. Biology of intertidal animals. Faversham, Kent: Marine Ecological Survey Ltd.

Peer, D.L., L.E. Linkletter, and P.W. Hicklin. 1986. Life history and reproductive biology of Corophium volutator (Crustacea: Amphipoda) and the influence of shorebird predation on population structure in Chignecto Bay, Bay of Fundy, Canada. Netherlands Journal of Sea Research. 20: 359-373.

Pezold, F. 2004. Redescriptions and synonymies of species of the American-West African genus Gobionellus (Teleostei, Gobiidae) with a key to species. Copeia 2004: 281-297.

Pollet, M., and S.E. Brooks. 2008. Long-legged flies (Diptera: Dolichopodidae). In Encyclopedia of Entomology. Vol 2. 2nd ed., ed. J.L. Capinera, 2232-2241. Springer Netherland.

Puyo, J. 1949. Faune de l'Empire Français. XII. Poissons de la Guyane Française. Office de la Recherche Outre-Mer. Paris.

Robins, C.R., G.C. Ray, and J. Douglass. 1999. A field guide to Atlantic Coast fishes: North America. The Peterson Field Guide Series Houghton Mifflin Company, Boston, USA. $354 \mathrm{pp}$.

Shannon, C.E. and W. Weaver. 1949. The mathematical theory of communication. The University of Illinois Press, Urbana, 117pp.

Swennen, C., P. Duiven, and A.L. Spaans. 1982. Numerical density and biomass of macrobenthic animals living in the intertidal zone of Surinam, South America. Netherlands Journal of Sea Research 15: 406-418.

Vargas, J.A. 1987. The benthic community of an intertidal mud flat in the Gulf of Nicoya, Costa Rica. Description of the community. Revista Biologia Tropical 35: 299-316.

Vasconcelos Filho, A.L., S. Neumann-Leitão, E. Eskinazi-Leça, R. Schwamborn, A.M.E. Oliveira, and M.N. Paranaguá. 2003. Trophic interactions between fish and other 
compartment communities in a tropical estuary in Brazil as indicator of environmental quality. WIT Transactions on Ecology and the Environment 63, 173-183.

Venturini, N., A.M.S. Pires-Vanin, M. Salhi, M. Bessonart, and P. Muniz. 2011. Polychaete response to fresh food supply at organically enriched coastal sites: Repercussion on bioturbation potential and trophic structure. Journal of Marine System 88: 526-541.

Wildsmith, M.D., T.H. Rose, I.C. Potter, R.M. Warwick, K.R. Clarke, and F.J. Valesini. 2009. Changes in the benthic macroinvertebrate fauna of a large microtidal estuary following extreme modifications aimed at reducing eutrophication. Marine Pollution Bulletin 58: 1250-1262.

Wolff, W.J., A.G. Duiven, P. Duiven, N.P. Esselink, P. Gueye, A. Meijboom, A. Moerland, and G. Zegers. 1993. Biomass of macrobenthic tidal flat fauna of the Banc d'Arguin, Mauritania. Hydrobiologia 258: 151-163.

Wyanski, D.M., and T.E. Targett. 2000. Development of transformation larvae and juveniles of Ctenogobius boleosoma, Ctenogobius shufeldti, and Gobionellus oceanicus (Pisces: Gobiidae) from western North Atlantic estuaries, with notes on early life history. Bulletin of Marine Science 67: 709-728. 


\section{List of Table Captions}

587

588 Table 1 Location and sedimentary characteristics of the 25 stations sampled in April 2012 in French Guiana and Suriname.

590 Table 2 Densities (ind. $\mathrm{m}^{-2}$ ) of each OTU for the 25 stations (coded by letters) sampled in 591 April 2012 in French Guiana and Suriname. Total number of OTU per station and per site (in

592

593

594

595

596

597

598

599

600

601

602

603

604

605

606

607 Warappa, values in brackets refer to the number of OTU for transect and nearshore stations, respectively). Total occurrences (Occ.) (percentage of stations where the OTU were present) for each OTU over the whole study area are also given.

Table 3 Average percent similarities within clusters and percent OTU contribution to the average similarities within clusters identified in the study area in April 2012 (A: Awala. B:

Bigi Pan. Wo: Warappa offshore. Wn: Warappa nearshore - SIMPER: OTU contribution cutoff $>90 \%$ ). For outliers A2 and W7, individual frequencies within stations are shown (cutoff $>90 \%$ of total abundance within each station). Letters in parenthesis indicate the faunal group to which the individual OTU belongs (P: polychaetes; T: tanaids; G: gastropods; F: fishes and I: insects).

Table 4 Ratios of dissimilarity to standard deviation (Diss. /SD) and the percent contributions of various OTU to dissimilarities (Contrib \%) between clusters identified in the study area in April 2012 (A: Awala. B: Bigi Pan. Wo: Warappa offshore. Wn: Warappa nearshore). Only OTU detected by SIMPER as good discriminating OTU (Diss/SD > 1.5; Wildsmith et al. 2009) are presented. Highest contributions (> 10\%) are in bold face. Letters in parenthesis as in Table 3. 


\section{List of figure captions}

611 Fig. 1 Map showing the study area and the location of the study sites sampled in French

612 Guiana and Suriname in April 2012, with locations of sampling stations at each study sites.

613 Fig. 2 Mean richness (A), mean densities (B) and mean H' diversity (C) measured at the 25 614 stations sampled in April 2012 in French Guiana and Suriname (A: Awala. B: Bigi Pan. W:

615 Warappa).

616 Fig. 3 Non-metric multidimensional scaling (MDS) ordination compiled from fourth root-

617 transformed OTU densities (ind. $\mathrm{m}^{-2}$ ) based on Bray Curtis similarities of the 25 stations

618 sampled in April 2012 in French Guiana and Suriname (A: Awala. B: Bigi Pan. W: Warappa);

619 overlaid clusters (black lines; 50\% Bray-Curtis similarity level) correspond to genuine

620 clusters defined by the SIMPROF routine (5\% significance level). 


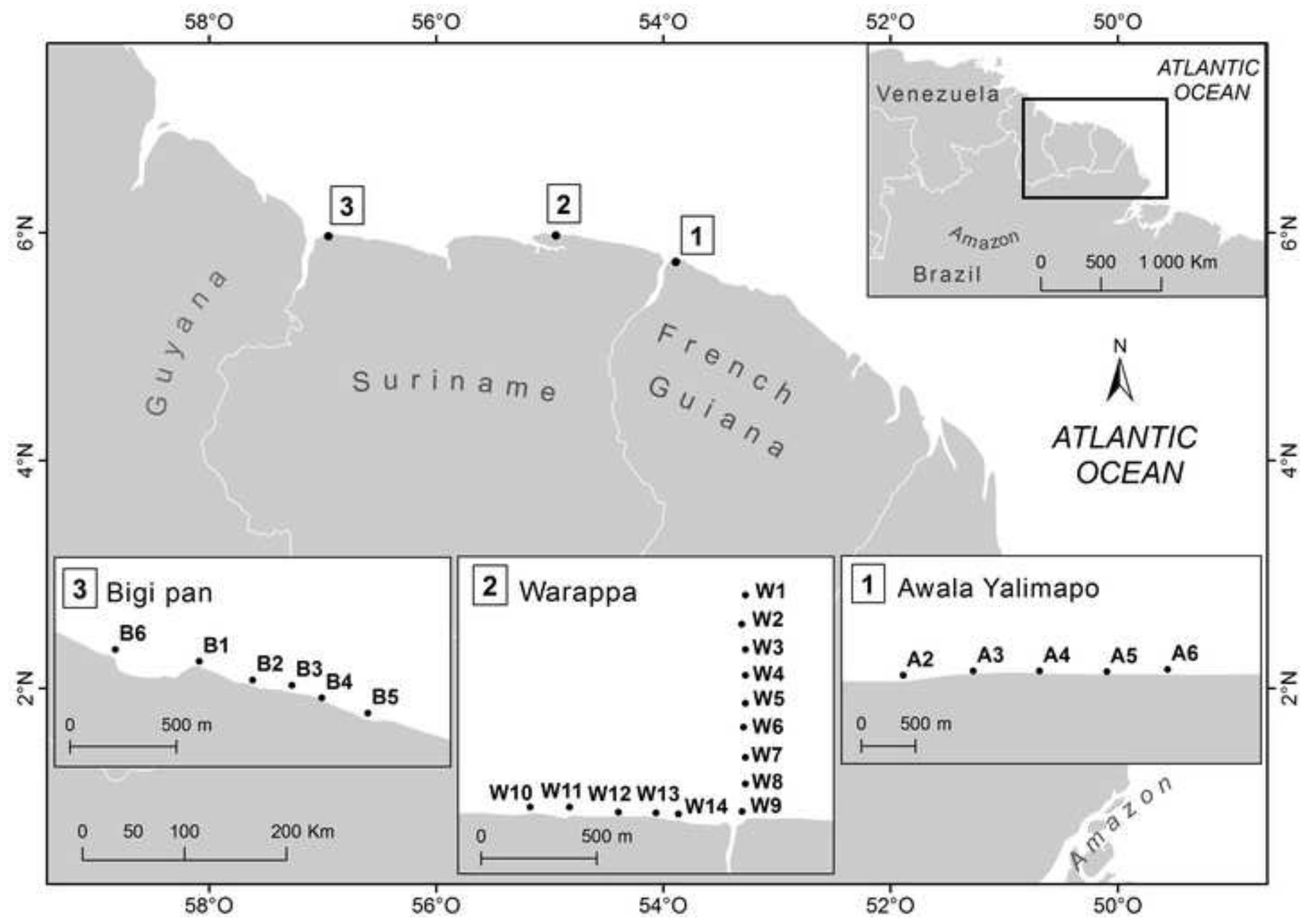



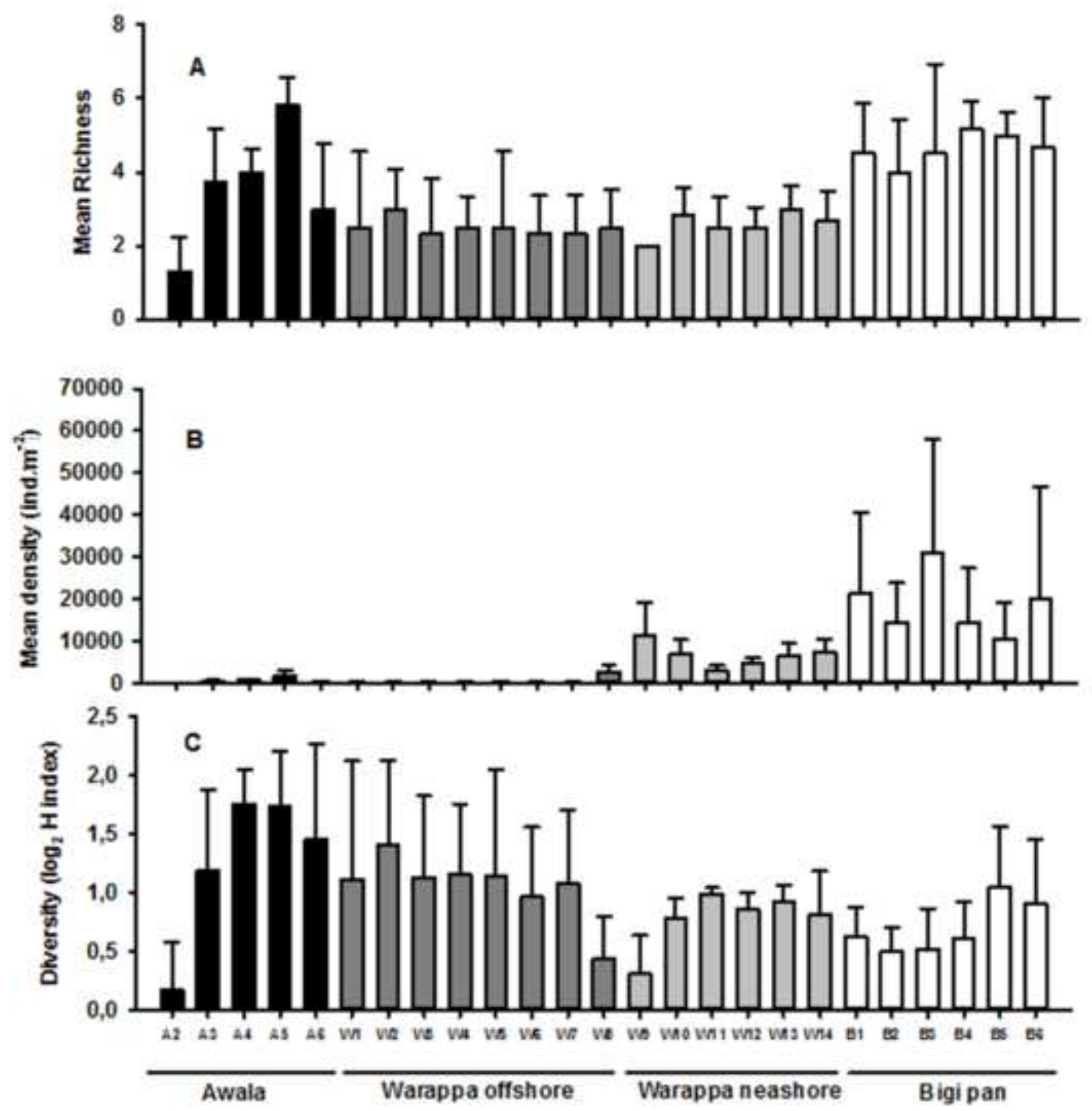

Study Sites 


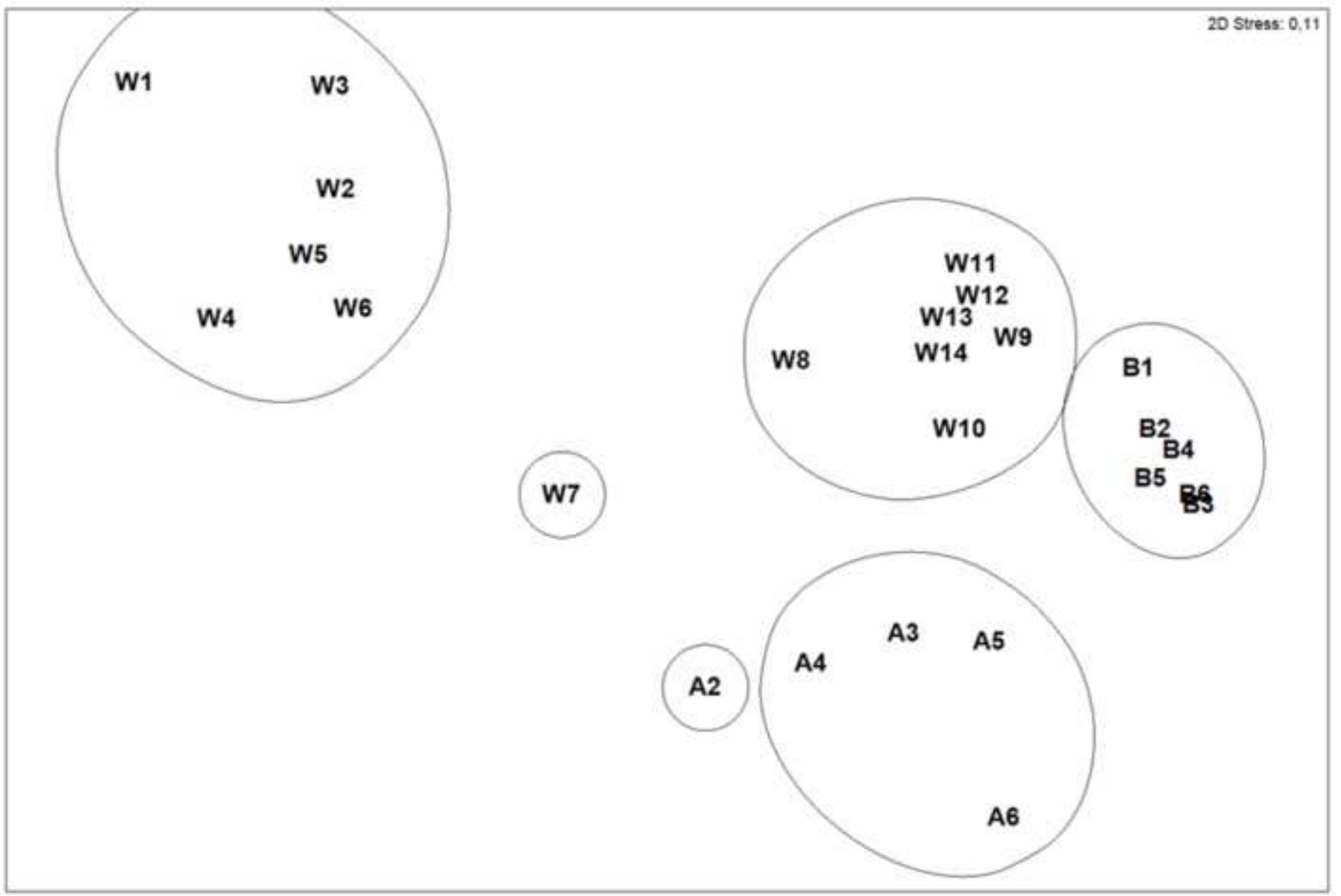




\begin{tabular}{|c|c|c|c|c|c|}
\hline \multirow[t]{3}{*}{ Study site } & \multirow{3}{*}{ Station } & \multicolumn{2}{|c|}{ Station coordinates } & \multicolumn{2}{|c|}{ Sediment characteristics } \\
\hline & & Latitude & Longitude & Mean grain size & Sediment $<63 \mu \mathrm{m}$ \\
\hline & & & & $\mu \mathrm{m}$ & $\%$ \\
\hline \multirow[t]{5}{*}{ Awala-Yalimapo } & $\mathrm{A} 2$ & $53^{\circ} 55^{\prime} 26.3^{\prime \prime} \mathrm{W}$ & $5^{\circ} 44^{\prime} 44.1^{\prime \prime} \mathrm{N}$ & 5.9 & 100 \\
\hline & A3 & $53^{\circ} 55^{\prime} 16.5^{\prime \prime} \mathrm{W}$ & $5^{\circ} 44^{\prime} 44.7^{\prime \prime} \mathrm{N}$ & 5.9 & 100 \\
\hline & A4 & $53^{\circ} 55^{\prime} 07.2^{\prime \prime} \mathrm{W}$ & $5^{\circ} 44^{\prime} 44.7 " \mathrm{~N}$ & 5.6 & 99.9 \\
\hline & A5 & $53^{\circ} 54^{\prime} 57.8^{\prime \prime} \mathrm{W}$ & $5^{\circ} 44^{\prime} 44.6 " \mathrm{~N}$ & 5.5 & 100 \\
\hline & A6 & $53^{\circ} 54^{\prime} 49.3^{\prime \prime W}$ & $5^{\circ} 44^{\prime} 44.9^{\prime \prime} \mathrm{N}$ & 5.3 & 100 \\
\hline \multicolumn{6}{|l|}{ Warappa } \\
\hline \multirow[t]{8}{*}{ Transect stations } & W1 & $54^{\circ} 54^{\prime} 45.6^{\prime \prime W}$ & $6^{\circ} 00^{\prime} 36.0 " \mathrm{~N}$ & 19.2 & 76.5 \\
\hline & W2 & $54^{\circ} 54^{\prime} 46.7^{\prime \prime W}$ & $6^{\circ} 00^{\prime} 27.4 " \mathrm{~N}$ & 14.9 & 80.3 \\
\hline & W3 & $54^{\circ} 54^{\prime} 45.6^{\prime \prime W}$ & $6^{\circ} 00^{\prime} 19.8 " \mathrm{~N}$ & 9.5 & 89.9 \\
\hline & W4 & $54^{\circ} 54^{\prime} 45.6^{\prime \prime} \mathrm{W}$ & $6^{\circ} 00^{\prime} 12.1 " \mathrm{~N}$ & 16.6 & 78.3 \\
\hline & W5 & $54^{\circ} 54^{\prime} 45.6^{\prime \prime} \mathrm{W}$ & $6^{\circ} 00^{\prime} 03.8 " \mathrm{~N}$ & 12.2 & 86.0 \\
\hline & W6 & $54^{\circ} 54^{\prime} 46.1 " \mathrm{~W}$ & $5^{\circ} 59^{\prime} 59.6 " \mathrm{~N}$ & 14.1 & 81.9 \\
\hline & W7 & $54^{\circ} 54^{\prime} 45.6^{\prime \prime} \mathrm{W}$ & $5^{\circ} 59^{\prime} 47.6 " \mathrm{~N}$ & 6.0 & 99.5 \\
\hline & W8 & $54^{\circ} 54^{\prime} 45.6^{\prime \prime} \mathrm{W}$ & $5^{\circ} 59^{\prime} 39.7^{\prime \prime} \mathrm{N}$ & 6.8 & 97.4 \\
\hline \multirow[t]{6}{*}{ Nearshore stations } & W9 & $54^{\circ} 54^{\prime} 45.6^{\prime \prime} \mathrm{W}$ & $5^{\circ} 59^{\prime} 31.5^{\prime \prime} \mathrm{N}$ & 6.6 & 96.5 \\
\hline & W10 & $54^{\circ} 55^{\prime} 50.1^{\prime \prime} \mathrm{W}$ & $5^{\circ} 59^{\prime} 32.9^{\prime \prime} \mathrm{N}$ & 5.5 & 99.7 \\
\hline & W11 & $54^{\circ} 55^{\prime} 28.8^{\prime \prime} \mathrm{W}$ & $5^{\circ} 59^{\prime} 31.2^{\prime \prime} \mathrm{N}$ & 5.3 & 99.8 \\
\hline & W12 & $54^{\circ} 55^{\prime} 23.6^{\prime \prime} \mathrm{W}$ & $5^{\circ} 59^{\prime} 31.3 " \mathrm{~N}$ & 5.5 & 99.8 \\
\hline & W13 & $54^{\circ} 55^{\prime} 12.4^{\prime \prime} \mathrm{W}$ & $5^{\circ} 59^{\prime} 31.1 " \mathrm{~N}$ & 5.7 & 98.6 \\
\hline & W14 & $54^{\circ} 55^{\prime} 05.7^{\prime \prime} \mathrm{W}$ & $5^{\circ} 59^{\prime} 30.8^{\prime \prime} \mathrm{N}$ & 5.7 & 99.5 \\
\hline \multirow[t]{6}{*}{ Bigi Pan } & B1 & $56^{\circ} 53 ' 28.6^{\prime \prime} \mathrm{W}$ & $5^{\circ} 59^{\prime} 17.7^{\prime \prime} \mathrm{N}$ & 7.9 & 92.7 \\
\hline & B2 & $56^{\circ} 53^{\prime} 20.5^{\prime \prime} \mathrm{W}$ & $5^{\circ} 59^{\prime} 14.9^{\prime \prime} \mathrm{N}$ & 6.5 & 96.4 \\
\hline & B3 & $56^{\circ} 53^{\prime} 14.5^{\prime \prime} \mathrm{W}$ & $5^{\circ} 59^{\prime} 14.1 " \mathrm{~N}$ & 6.4 & 97.3 \\
\hline & B4 & $56^{\circ} 53^{\prime} 10.0^{\prime \prime} \mathrm{W}$ & $5^{\circ} 59^{\prime} 12.2^{\prime \prime} \mathrm{N}$ & 5.9 & 98.6 \\
\hline & B5 & $56^{\circ} 53^{\prime} 03.0^{\prime \prime} \mathrm{W}$ & $5^{\circ} 59^{\prime} 09.9^{\prime \prime} \mathrm{N}$ & 8.6 & 91.2 \\
\hline & B6 & $56^{\circ} 53^{\prime} 41.3^{\prime \prime W}$ & $5^{\circ} 59^{\prime} 19.5^{\prime \prime} \mathrm{N}$ & 9.5 & 89.3 \\
\hline
\end{tabular}




\begin{tabular}{|c|c|c|c|c|c|c|c|c|c|c|c|c|c|c|c|c|c|c|c|c|c|c|c|c|c|c|}
\hline \multirow[b]{2}{*}{ OTU } & \multicolumn{5}{|c|}{ Awala } & \multicolumn{14}{|c|}{ Warappa } & \multicolumn{6}{|c|}{ Bigi Pan } & \multirow{2}{*}{$\frac{\text { Occ. }}{\%}$} \\
\hline & A2 & $\mathbf{A 3}$ & A4 & A5 & A6 & w1 & W2 & w3 & W4 & W5 & W6 & w7 & w8 & w9 & W10 & W11 & W12 & W13 & W14 & B1 & B2 & B3 & B4 & B5 & B6 & \\
\hline \multicolumn{27}{|l|}{ Crustacean } \\
\hline Halmyrapseudes spaansi & 18 & 206 & 54 & 242 & 18 & 10 & 49 & 59 & 10 & 69 & 69 & 20 & 2,255 & 10,951 & 5,538 & 1,846 & 3,136 & 4,462 & 5,296 & 19,185 & 13,190 & 27,957 & 13,297 & 7,966 & 16,846 & 100 \\
\hline Discapseudes surinamensis & & 9 & & & & & & & & & & 10 & & & & & & & & 1,084 & & 2,428 & 215 & 1,873 & 2,688 & 28 \\
\hline Gnathiidae & & & & & & & 20 & & & & & & & & & 18 & 27 & & 9 & & & & & & & 16 \\
\hline Isopoda & & & & & & & & & & & 10 & 10 & 10 & & & & & & & & & & & & & 12 \\
\hline Mysidacea & & & 9 & & & & & & & & & & & & & & & 9 & & & & & & & & 8 \\
\hline Uca maracoani & & & & & & & & & & & & & & & & & & & & 54 & 9 & & & & & 8 \\
\hline Callinectes bocourti & & 9 & & & & & & & & & & & & & & & & & & & & & & & & 4 \\
\hline \multicolumn{27}{|l|}{ Polychaetes } \\
\hline Sigambra grubii & 45 & 152 & 179 & 896 & 63 & & & & & & & 20 & 137 & 275 & 1,272 & 1,075 & 1,622 & 1,774 & 1,935 & 645 & 780 & 430 & 475 & 269 & 278 & 76 \\
\hline Lumbrineridae & & & & & & 10 & 10 & 59 & 108 & 69 & 20 & 10 & 10 & & & & & & & & & & & & & 32 \\
\hline Heteromastus sp. & & & & & & & & & & & & 10 & & & & & & & & 45 & 54 & 45 & 116 & 63 & 45 & 28 \\
\hline Mediomastus sp. & & & 27 & 36 & & & 10 & & 10 & 20 & 167 & 29 & & & & & & & & & & & & & & 28 \\
\hline Alitta sp. & & & & & & 20 & 29 & 20 & 10 & 29 & 10 & & & & & & & & & & & & & & & 24 \\
\hline Orbinidae & & & & & & 20 & 10 & 10 & & 10 & & & & & & & & & & & & & & & & 16 \\
\hline Streblospio gynobranchiata & & 9 & 188 & 18 & & & & & & & & & & & 9 & & & & & & & & & & & 16 \\
\hline Phyllodoce sp. & & & & & & & & & & & & & & & & & & & & 36 & & & 18 & & & 8 \\
\hline Polychaeta & & & & & & & 10 & & & & 10 & & & & & & & & & & & & & & & 8 \\
\hline Capitella sp. & & & & & 9 & & & & & & & & & & & & & & & & & & & & & 4 \\
\hline Capitellidae & & & & & & & & & & & & 39 & & & & & & & & & & & & & & 4 \\
\hline Glycinde multidens & & & & & & & & 10 & & & & & & & & & & & & & & & & & & 4 \\
\hline Nephtys sp. & & & & & & & & & & & & & & & & 9 & & & & & & & & & & 4 \\
\hline \multicolumn{27}{|l|}{ Oligochaetes } \\
\hline Oligochaeta & & & & & & & 10 & & 39 & & 10 & 29 & 10 & & 18 & & & 18 & 9 & 9 & & & & & & 36 \\
\hline Nemertea & & & & & & & & & & & & & & & & & & & & & & & & & & \\
\hline Nemertea & 9 & & & 9 & & & & & & & & & 10 & & 9 & & & & & & & 9 & & & & 20 \\
\hline \multicolumn{27}{|l|}{ Molluses } \\
\hline Bivalves & & & & & & & & & & & & & & & & & & & & & & & & & & \\
\hline Macoma constricta & & & & 9 & 9 & & & & & & & & & & 9 & & & & & & 18 & & 9 & & 9 & 24 \\
\hline Mulinia cleryana & & & & 36 & 18 & & & & & & & & & & & & & & & & & 9 & & 18 & 9 & 20 \\
\hline Ennucula dalmasi & & & & & & 49 & 20 & 10 & & & & & & & & & & & & & & & & & & 12 \\
\hline Nuculana concentrica & & & & & & & 20 & & 10 & & & & & & & & & & & & & & & & & 8 \\
\hline Eurytellina trinitatis & & & & & & 10 & & & & & & & & & & & & & & & & & & & & 4 \\
\hline Tagelus plebeius & & & & & & & & & & & & & & & & & & 27 & & & & & & & & 4 \\
\hline Tellinidae & & & & & & & & & & & & & & & & & & & & & & 9 & & & & 4 \\
\hline
\end{tabular}


Gastropods

Assiminea succinea

Cylichnella bidentata

Odostomia solidula

Olivella olssoni

Parvanachis obesa

Turbonilla sp.

Insects

Dolichopodidae larvae

Insecta larvae

Fishes

Gobionellus oceanicus

Total number of OTU per station Total number of OTU per site

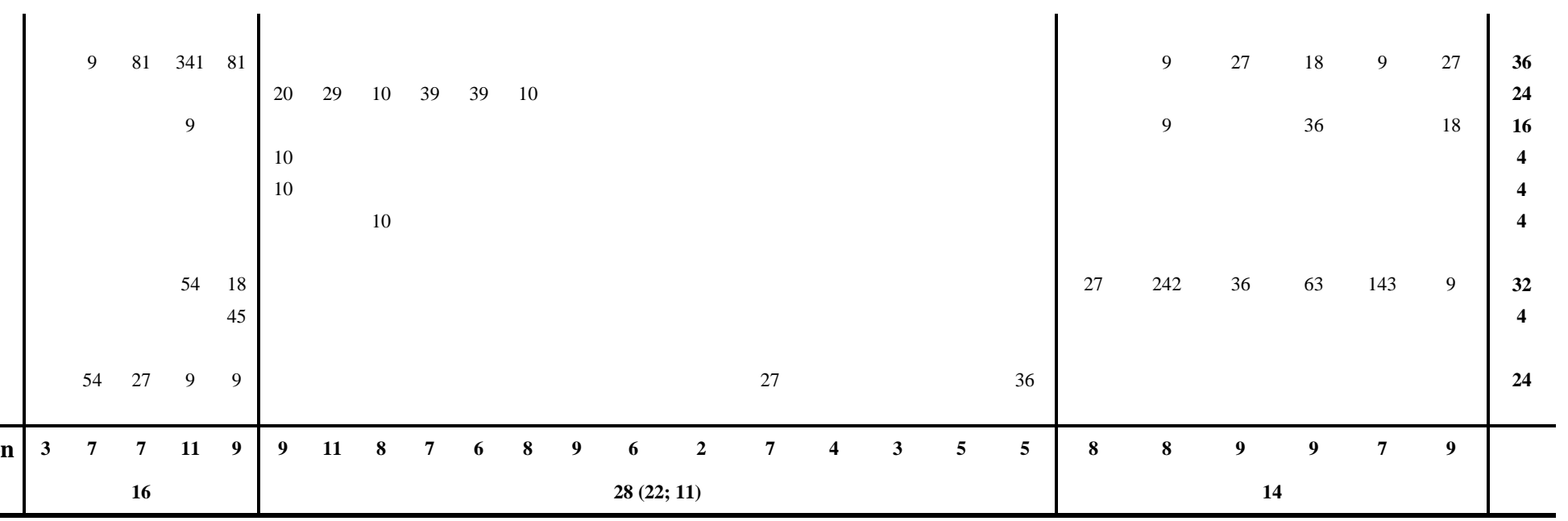




\begin{tabular}{lcccccc}
\hline \multirow{2}{*}{ Stations } & A & B & Wo & Wn & A2 & W7 \\
\cline { 2 - 6 } & & & & & & \\
Average similarity (\%) & 56.2 & 77.2 & 60.5 & 70.6 & - & - \\
\hline & & & & & & \\
Halmyrapseudes spaansi (T) & 21.3 & 40.7 & 20.7 & 56.4 & 25.0 & 11.1 \\
Sigambra grubii (P) & 26.7 & 16.8 & & 36.7 & 62.5 & 11.1 \\
Assiminea succinea (G) & 19.5 & & & & & \\
Gobionellus oceanicus (F) & 15.4 & & & & & \\
Streblospio gynobranchiata (P) & 7.5 & & & & & \\
Discapseudes surinamensis (T) & & 13.4 & & & & 5.6 \\
Heteromastus sp. (P) & & 10.2 & & & & 5.6 \\
Dolichopodidae (I) & & 8.9 & & & & \\
Lumbrineridae (P) & & & 19.9 & & & \\
Cylichnella bidentata (G) & & & 18.9 & & & \\
Alitta sp. (P) & & & 18.4 & & & \\
Mediomastus sp. (P) & & & 7.0 & & & \\
Orbiniidae (P) & & & & & & \\
Nemertea & & & & & & \\
Capitellidae (P) & & & & & \\
Oligochaeta & & & & & \\
& & & & & & \\
\hline
\end{tabular}




\begin{tabular}{|c|c|c|c|c|c|c|c|c|c|c|c|c|}
\hline \multirow{3}{*}{ Average dissimilarity (\%) } & \multicolumn{2}{|c|}{$\mathrm{A} / \mathrm{B}$} & \multicolumn{2}{|c|}{ A/Wo } & \multicolumn{2}{|c|}{$\mathrm{A} / \mathrm{Wn}$} & \multicolumn{2}{|c|}{$\mathrm{B} / \mathrm{Wo}_{0}$} & \multicolumn{2}{|c|}{$\mathrm{B} / \mathrm{Wn}$} & \multicolumn{2}{|c|}{ Wo/Wn } \\
\hline & \multicolumn{2}{|c|}{60.14} & \multicolumn{2}{|c|}{84.68} & \multicolumn{2}{|c|}{60.87} & \multicolumn{2}{|c|}{89.72} & \multicolumn{2}{|c|}{50.52} & \multicolumn{2}{|c|}{81.09} \\
\hline & Diss/SD & Contrib\% & Diss/SD & Contrib\% & Diss/SD & Contrib\% & Diss/SD & Contrib\% & Diss/SD & Contrib\% & Diss/SD & Contrib\% \\
\hline Halmyrapseudes spaansi $(\mathrm{T})$ & 5.6 & 24.6 & & & 2.9 & 20.8 & 8.7 & 19.2 & 2.1 & 11.9 & 3.7 & 19.6 \\
\hline Sigambra grubii $(\mathrm{P})$ & 1.8 & 3.7 & 6.3 & 11.7 & 1.6 & 8.1 & 7.6 & 10.2 & 2.1 & 5.3 & 4.9 & 19.1 \\
\hline Discapseudes surinamensis $(\mathrm{T})$ & 2.0 & 14.4 & & & & & 2.0 & 11.0 & 2.0 & 19.2 & & \\
\hline Heteromastus sp. $(\mathrm{P})$ & 7.0 & 8.5 & & & & & 8.1 & 6.1 & 7.8 & 10.6 & & \\
\hline Assiminea succinea $(\mathrm{G})$ & & & 4.7 & 9.0 & 4.6 & 12.2 & 2.2 & 3.7 & 2.2 & 6.4 & & \\
\hline Alitta sp. (P) & & & 5.9 & 6.4 & & & 8.1 & 4.6 & & & 6.7 & 7.2 \\
\hline Cylichnella bidentata $(\mathrm{G})$ & & & 4.7 & 6.7 & & & 5.8 & 4.8 & & & 5.0 & 7.6 \\
\hline Lumbrineridae $(\mathrm{P})$ & & & 3.2 & 7.6 & & & 3.6 & 5.4 & & & 2.3 & 7.6 \\
\hline Gobionellus oceanicus $(\mathrm{F})$ & 3.7 & 6.5 & 3.3 & 6.7 & 1.7 & 7.1 & & & & & & \\
\hline Dolichopodidae (I) & & & & & & & 3.1 & 6.2 & 3.1 & 10.8 & & \\
\hline
\end{tabular}


ESM 1: Sediment granulometric fractions of the 25 stations sampled in French Guiana and Suriname in 2012. Additional data (organic matter (OM), chlorophyll $a$ (per dry weight, DW, of sediment) and concentration of prokaryotes in the sediment), and matching stations to those in the present study in Dupuy et al. (2015) are both in bold face.

\begin{tabular}{|c|c|c|c|c|c|c|c|c|c|}
\hline & & $\begin{array}{c}\text { Silt \& Clay } \\
\% \\
\end{array}$ & $\begin{array}{c}\text { Fine Sand } \\
\% \\
\end{array}$ & $\begin{array}{c}\text { Medium Sand } \\
\% \\
\end{array}$ & $\begin{array}{c}\text { Coarse Sand } \\
\% \\
\end{array}$ & $\begin{array}{c}\text { OM } \\
\%\end{array}$ & $\begin{array}{l}\text { Chlorophyll } a \\
\mu \mathrm{g} \cdot \mathrm{g}^{-1} \mathrm{DW} \text { sed }\end{array}$ & $\begin{array}{c}\text { Prokaryotes } \\
\text { Cells.mL }{ }^{-1}\end{array}$ & Dupuy et al (2015) \\
\hline \multirow{5}{*}{ Awala } & $\mathrm{A} 2$ & 100.0 & 0.0 & 0.0 & 0.0 & - & - & - & \\
\hline & A3 & 100.0 & 0.0 & 0.0 & 0.0 & - & - & - & \\
\hline & A4 & 99.9 & 0.1 & 0.0 & 0.0 & 6.0 & 18.8 & $2.5 \mathrm{E}+09$ & Awala StB \\
\hline & A5 & 100.0 & 0.0 & 0.0 & 0.0 & 6.0 & 15.3 & $2.5 E+09$ & Awala StC \\
\hline & $\mathrm{A} 6$ & 100.0 & 0.0 & 0.0 & 0.0 & - & - & - & \\
\hline \multirow{14}{*}{$\begin{array}{l}\text { Warappa } \\
\text { Kreek }\end{array}$} & W1 & 76.5 & 4.1 & 0.0 & 19.3 & - & - & - & \\
\hline & W2 & 80.3 & 4.8 & 0.0 & 14.8 & - & - & - & \\
\hline & W3 & 89.8 & 3.3 & 0.0 & 7.0 & - & - & - & \\
\hline & W4 & 78.3 & 2.1 & 0.0 & 19.6 & - & - & - & \\
\hline & W5 & 86.0 & 2.6 & 0.6 & 10.8 & - & - & - & \\
\hline & W6 & 81.9 & 2.5 & 0.0 & 15.7 & - & - & - & \\
\hline & W7 & 99.5 & 0.5 & 0.0 & 0.0 & - & - & - & \\
\hline & W8 & 97.4 & 2.6 & 0.0 & 0.0 & - & - & - & \\
\hline & W9 & 96.5 & 2.3 & 1.0 & 0.2 & - & - & - & \\
\hline & W10 & 99.7 & 0.3 & 0.0 & 0.0 & 6.2 & 8.6 & $2.8 \mathrm{E}+09$ & Warappa \\
\hline & W11 & 99.8 & 0.2 & 0.0 & 0.0 & - & - & - & \\
\hline & W12 & 99.8 & 0.2 & 0.0 & 0.0 & - & - & - & \\
\hline & W13 & 98.6 & 1.1 & 0.3 & 0.0 & - & - & - & \\
\hline & W14 & 99.5 & 0.5 & 0.0 & 0.0 & - & - & - & \\
\hline \multirow{6}{*}{ Bigi Pan } & B1 & 92.7 & 5.9 & 1.3 & 0.1 & - & - & - & \\
\hline & B2 & 96.4 & 2.6 & 0.9 & 0.2 & - & - & - & \\
\hline & B3 & 97.3 & 1.8 & 0.7 & 0.2 & - & - & - & \\
\hline & B4 & 98.6 & 1.4 & 0.0 & 0.0 & - & - & - & \\
\hline & B5 & 91.2 & 4.2 & 1.4 & 3.3 & 5.6 & 15.6 & 4.4E+09 & Nickerie \\
\hline & $\mathrm{B} 6$ & 89.3 & 3.4 & 0.6 & 6.7 & - & - & - & \\
\hline
\end{tabular}




\section{Transform: Fourth root}

Resemblance: S17 Bray Curtis similarity

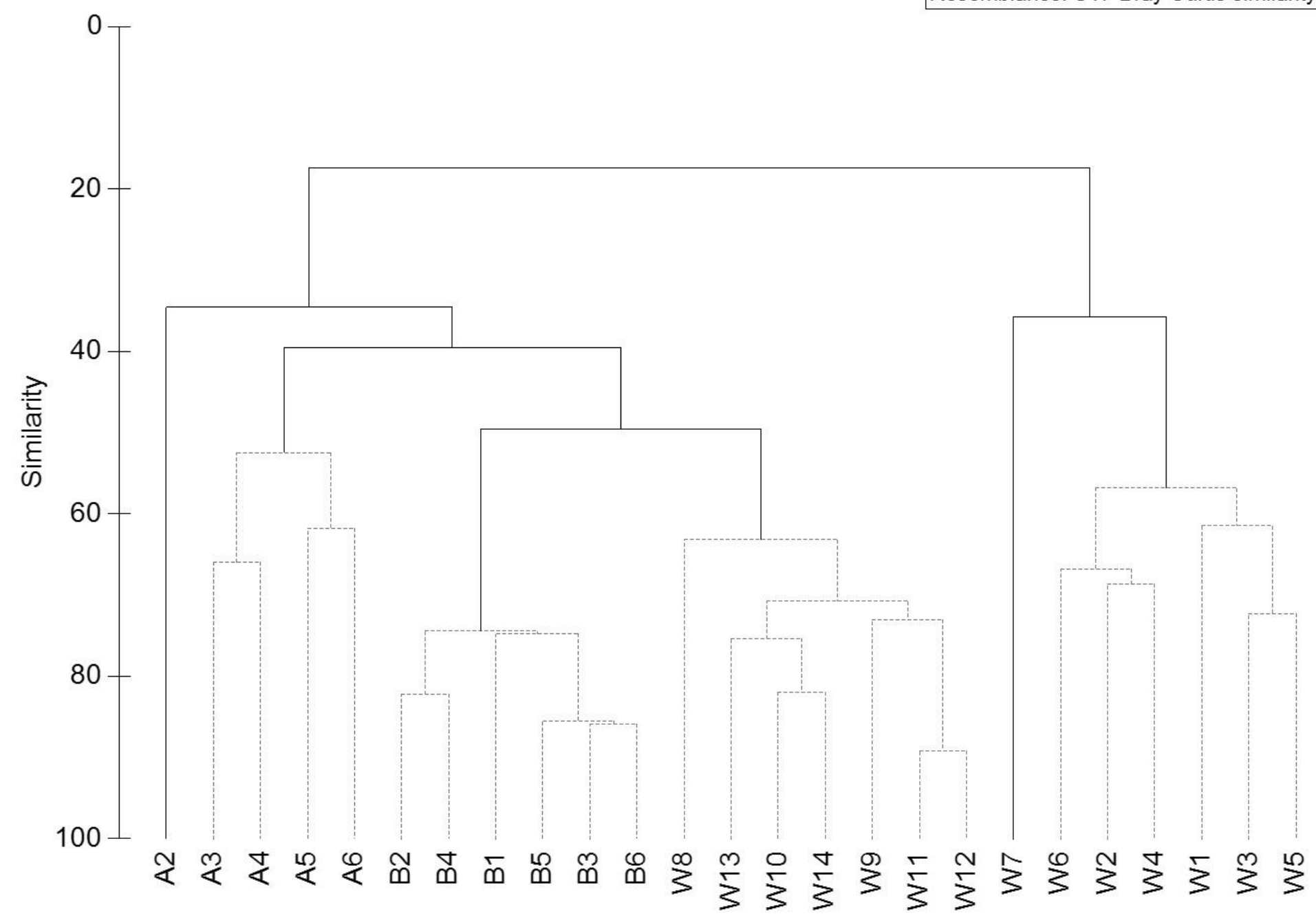

ESM 2: Dendrogram of hierarchical clustering compiled from fourth root-transformed densities of OTU based on Bray Curtis similarities of the 25 stations sampled in April 2012 in French Guiana and Suriname. Grey dotted clusters correspond to genuine clusters identified by the SIMPROF routine (A: Awala, B: Bigi Pan, W: Warappa). 

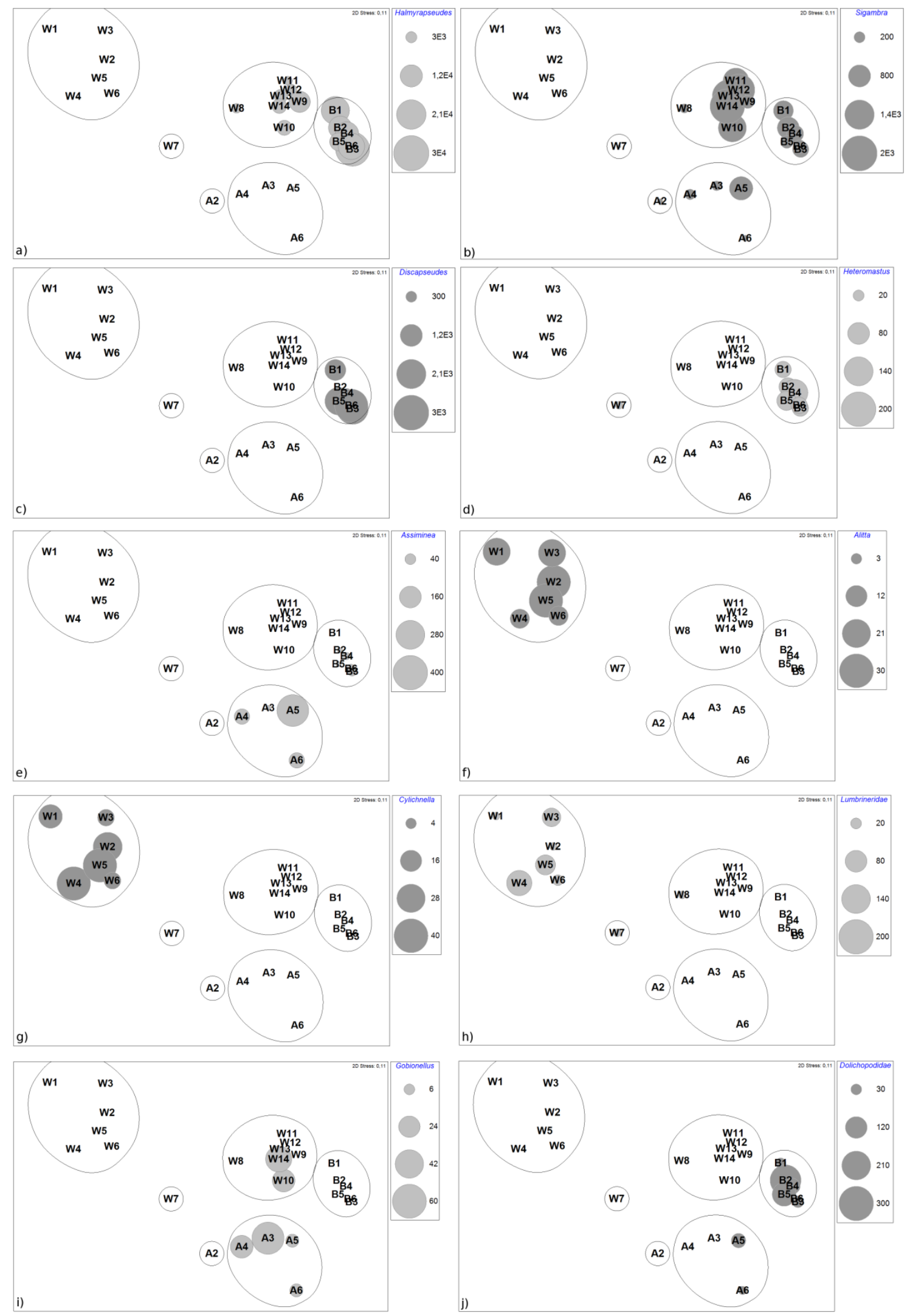

ESM 3: Bubble plots of densities (ind. $\mathrm{m}^{-2}$ ) of the ten "good discriminating" OTU (see text) generated by the SIMPER routine on the ordination plot of the 25 stations sampled in April 2012 in French Guiana and Suriname (A: Awala. B: Bigi Pan. W: Warappa); OTU are ranked following Table 4; overlaid clusters indicated by black 
lines (50\% Bray-Curtis similarity level) correspond to genuine clusters defined by the SIMPROF routine (5\% significance level). 